\title{
Relations industrielles
}

Industrial Relations

\section{The Shadow Welfare State: Labor, Business, and the Politics of Health Care in the United States by Marie GoTTSCHALK, Ithaca: Cornell University Press, 2000, 320 pp., ISBN 0-8014-3745-8 (cloth) and 0-8014-8648-3 (paper).}

\section{David Jacobs}

Volume 56, numéro 1, hiver 2001

URI : https://id.erudit.org/iderudit/000148ar

DOI : https://doi.org/10.7202/000148ar

Aller au sommaire du numéro

Éditeur(s)

Département des relations industrielles

ISSN

0034-379X (imprimé)

1703-8138 (numérique)

Découvrir la revue

Citer ce compte rendu

Jacobs, D. (2001). Compte rendu de [The Shadow Welfare State: Labor Business, and the Politics of Health Care in the United States by Marie GoTTSCHALK, Ithaca: Cornell University Press, 2000, 320 pp., ISBN 0-8014-3745-8 (cloth) and 0-8014-8648-3 (paper).] Relations industrielles / Industrial Relations, 56(1), 205-207. https://doi.org/10.7202/000148ar

Tous droits réservés (C Département des relations industrielles de l’Université Laval, 2001
Ce document est protégé par la loi sur le droit d'auteur. L'utilisation des services d'Érudit (y compris la reproduction) est assujettie à sa politique d'utilisation que vous pouvez consulter en ligne.

https://apropos.erudit.org/fr/usagers/politique-dutilisation/ 
Voir texte plus bas.

The Shadow Welfare State: Labor, Business, and the Politics of Health Care in the United States

by Marie GotTSCHALK, Ithaca: Cornell University Press, 2000, 320 pp., ISBN 0-8014-3745-8 (cloth) and 0-8014-8648-3 (paper).

Alone among industrialized nations, the United States lacks a program guaranteeing universal access to health care. In this context, Marie Gottschalk's The Shadow Welfare State: Labor, Business, and the Politics of Health Care in the United States, is an intelligent and encyclopaedic account of labour's efforts on behalf of health care reform in the U.S. This very well written and engaging 
book touches myriad issues in the history of labour, social democracy, and American political institutions.

The introduction stresses gaps in scholarship on labour, health policy, and the welfare state. Chapter 2 documents the poorly understood role of organized labour in the development of the "private welfare state" in the United States. Chapter 3 follows with a chronicle of labour's experience with job-based health benefits. In chapter 4, Gottschalk argues that American labour began to abandon its commitment to national health insurance in a capitulation to the politics of expediency in the years of the Carter presidency. Chapter 5 links labour's changing strategy on health care reform to misguided efforts to forge coalitions with big business. Chapters 6 and 7 set out Gottschalk's critique of labour's broad approach to political economy. The final chapter addresses the future of labour activism and health care reform.

Gottschalk contends that labour's increasing investment in a private health care system, particularly its reliance upon health and welfare funds jointly administered with employers, has dulled its appetite for fundamental health care reform: the goal of universal health insurance. Although labour movements around the world have traditionally supported socialized medicine, in the $1980 \mathrm{~s}$ the AFL-CIO and many affiliated unions turned toward the strategy of an employer mandate, rather than a "singlepayer," government health insurance system. In explaining this shift, Gottschalk stresses the role of institutions, that is, the inertial effects of union investment in a private insurance system. She also argues that unions became increasingly allied with employers in combating the perils of international competition and therefore came to expect that employers dissatisfied with health care costs would be allies for health care reform.
Gottschalk believes that unions should have joined public interest groups in a campaign for a single-payer system rather than seek alliances in the business community. Especially in an era in which enterprises offer increasingly unstable employment and declining prospects for careers, it seems particularly inappropriate to base health care access on place of employment. Moreover, strategic alliances with employers place unions in a political bind and disappoint labour's real allies among the downtrodden.

Gottschalk makes some errors in her analysis, however. In particular, she seems to mistake the 1991 AFL-CIO health-care committee's deadlock on the single-payer approach and the federation's subsequent embrace of the employer mandate approach (in support of Democratic Party initiatives for health care reform) for a fundamental ideological shift. Unions have often sponsored welfare funds whose value in organizing has dampened enthusiasm for government programs like single payer. The building trades' link to the profit-making Union Labor Life Insurance Company has had this effect. That a segment of organized labour is cool to some governmental solutions to workers' problems is not a new development.

On the other hand, the more liberal industrial and public sector unions have long been sympathetic to the single-payer approach and other social democratic initiatives that serve union members and the broader working class. The United Auto Workers led the campaign for single-payer national health insurance from the 1960s into the 1980s. The American Federation of State, County, and $\mathrm{Mu}-$ nicipal Employees has been a leading backer of the single-payer approach more recently. With the defeat of the Clinton approach, some union leaders have returned to vocal advocacy of a single-payer strategy. It remains to be seen whether they will have another 
opportunity to set the official policy of the AFL-CIO.

That particular arrangements with employers might moderate unions' reformist zeal is an historical and contemporary reality. Every union contract with an employer potentially invites some form of "co-optation." For this reason, among others, the Industrial Workers of the World disavowed all contracts. They clearly avoided the peril of unholy alliances with business, but they also lost the opportunity to preserve any gains won for workers through their militancy.

I believe that Gottschalk lays too much blame for the defeat of health care reform on organized labour. Far more important were the effects of U.S. political institutions. In particular, the structure of the Senate-notably, the fact that small conservative states have as many senators as the most populous and labour-friendly ones-gave conservative opponents of health care reform an advantage. Moreover, through the filibuster and other tactics of delay, conservatives have multiple means to frustrate potential Senate majorities. President Clinton was under the illusion that his complicated version of health care reform would win the support of swing senators and a sizeable subset of employers, but he underestimated the opposition of conservative ideologues who viewed any scheme of universal health insurance as a threat to capitalism. Undoubtedly, labour and other advocates of health care reform made strategic errors, but we must remember that the obstacles to reform are formidable in the U.S. context.

Gottschalk uses the health care reform case as the basis of a searching examination of the dilemmas facing organized labour in the United States. All labour scholars will find her book a rich source of analysis and information on a wide variety of topics. What she says about the forces promoting labour conservatism has merit. It is her grand argument of labour capitulation that misses the mark.

DAVID JACOBS American University 